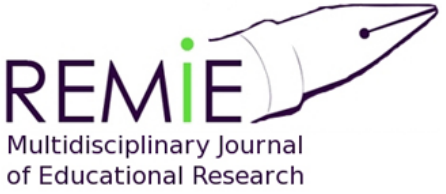

Multidisciplinary Journal

of Educational Research
Hipatia Press

www.hipatiapress.com

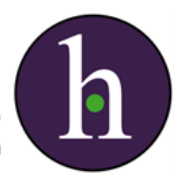

Instructions for authors, subscriptions and further details:

http://remie.hipatiapress.com

\title{
Adult's Participation in Work-related Training: The Balance between Improving Job and a Desire for Learning
}

Ana Inés Renta-Davids ${ }^{1}$, Manel Fandos-Garrido ${ }^{1}$, José Miguel Jiménez-González ${ }^{1}$, Ángel Pío González-Soto ${ }^{1}$

1) Universitat Rovira i Virgili. Spain

Date of publication: February $15^{\text {th }}, 2016$

Edition period: February 2016 - June 2016

To cite this article: Renta-Davids, A. I., Fandos-Garrido, M., JimenezGonzález, J. M., \& González-Soto, A. P. (2016). Adult's participation in workrelated training: the balance between improving job and a desire for learning. Multidisciplinary Journal of Educational Research, 6(1), 1-22. doi:10.17583/remie.2016.1531

To link this article: http://dx.doi.org/10.17583/remie.2016.1531

\section{PLEASE SCROLL DOWN FOR ARTICLE}

The terms and conditions of use are related to the Open Journal System and to Creative Commons Attribution License (CC-BY). 


\section{Adult's Participation in Work- related Training: The Balance between Improving Job and a Desire for Learning}

Ana Inés Renta-Davids

Universitat Rovira $i$ Virgili

José Miguel Jiménez-González

Universitat Rovira i Virgili
Manel Fandos-Garrido

Universitat Rovira i Virgili

Ángel Pío González-Soto

Universitat Rovira i Virgili

\section{Abstract}

The study draws on findings from a survey of adults in non-formal continuing education under the professional training for employment framework in Spain. Quantitative analysis was carried out to a sample of 425 respondents from three different educational providers. Firstly, a factor analysis was conducted to fourteen motives for participation items. A two-dimension model of motivation to participate was identified: one dimension oriented towards job-improvement and the other dimension oriented towards learning. Secondly, a variance analysis was conducted according to demographics variables. Results showed significant statistical differences in the first dimension according to demographic variables. This might indicates an instrumental motivation in participation in work-related training among different groups who try to cope with different types of drawbacks.

Keywords: adult learning, work-related training, lifelong learning 


\section{Participación de las Personas Adultas en la Formación relacionada con el Empleo: Equilibrio entre la Mejora del Trabajo y el Deseo de Aprender}

Ana Inés Renta-Davids

Universitat Rovira $i$ Virgili

José Miguel Jiménez-González

Universitat Rovira i Virgili
Manel Fandos-Garrido

Universitat Rovira i Virgili

Ángel Pío González-Soto

Universitat Rovira i Virgili

\section{Resumen}

El presente estudio muestra resultados de una encuesta aplicada a participantes de cursos de formación continua bajo el marco del Subsistema de Formación para el Empleo en España. El estudio analiza cuáles son las razones de los trabajadores, ocupados y desocupados, para participar en formación para empleo. Se realizó un análisis cuantitativo a una muestra de 425 registros. En primer lugar, se realizó un análisis factorial sobre catorce ítems que indicaban razones de participación. Se identificó una estructura bidimensional: una dimensión orientada al aprendizaje y otra orientada a la mejora del empleo. En segundo lugar, se realizó un análisis de la varianza de acuerdo a variables demográficas. Los resultados muestran diferencias significativas en la dimensión relacionada con la mejora del empleo. Este resultado indicaría que diferentes grupos participan en formación continua con el fin de superar sus desventajas.

Palabras clave: educación de adultos, formación para el trabajo, aprendizaje a lo largo de la vida 
dult learning has become a policy priority for economic growth and social development in industrialized countries (Pont, 2004). In 2011, the European Commission set a renewed agenda for Adult Education highlighting its major role as a mean to achieve the Europe 2020 goals, by enabling adults to adapt to changes in the labour market and society. The European Council resolution states that 'adult learning provides a means of up-skilling and reskilling those affected by unemployment, restructuring and career transitions, as well as makes an important contribution to social inclusion, active citizenship and personal development' (European Commission, 2011a). The Europe 2020 goals in the field of adult education set a benchmark of 15\% of adults aged 24-64 should be taking part in learning activities. Currently, participation of adults in learning activities varies greatly between European countries: overall, the numbers go from $1.4 \%$ to $31.6 \%$, where Spain's figure is $10.4 \%$ according to the European Labour Survey Force (European Commission, 2011b). While educational provision and participation has increase in general population, yet remains unequal across population subgroups (European Union, 2013). Many researchers continue to be interested in understanding the reasons why adults participate in learning activities and in determining the factors that influence this decision. Why some adults participate in training while others do not is an interesting social question, above all when there is evidence that participation in training is not distributed uniformly across the population.

The emphasis placed on lifelong learning, both in terms of economic benefits and social inclusion, have increased the social relevance of this area of research. Furthermore, this question has a practical relevance for providers of training, who have an interest in developing training programmes that meet the needs and demands of participants and social agents.

The present research analyses adults' motivation to participate to workrelated training. The study examined how adult motivation for non-formal work-related training is affected by demographic variables such as gender, age, educational level, and labour status. The questions we raise are: what motivates adults to participate in work-related training? Does motivation to 
participate in work-related training differ according to demographics variables?

The article brings together the evidence from previous studies which show that participation in training is distributed unevenly throughout the adult population and that this is explained in part by individual differences. Likewise, the article also takes from previous studies the idea that adults' motivation for participating in training is composed of multiple reasons that are not mutually exclusive. In this article we analyse what motivates adults to participate in work-related training. It is clear that by analysing the motivation for participating in a very specific type of training, adults' reasons for participating will be oriented in this direction; that is, towards getting a job or maintaining and/or improving their current job. Even so, we still want to know if in addition to these reasons there are any others related to enjoyment of learning, personal development or other social aspects. The presence of a type of motivation oriented towards enjoyment of learning or personal development would indicate a profile of participants who are mobilized not only by external conditions imposed on them by the requirements of their job and the need to immediately apply knowledge, but also by an internal motivation oriented towards acquisition of knowledge and personal development.

\section{Theoretical Background}

\section{Patterns of Participation and Reasons for Participating}

Research on participation of adults in education, be this formal, non-formal or informal, has been taking place for some time now and has led to the publication of many studies. Among the literature that has been generated in previous years are some important studies that consistently identify the profile of adults that participate in training. One of the early studies in this area was by Johnstone and Rivera (1965), who stated that the typical adults taking part in training were young, highly educated, in full time work and with a high income. Most recent studies have thrown up similar results, albeit it with certain nuances. Chisholm, Larson and Mossoux (2004) present 
a study based on data collected from large-scale international surveys in which they provide evidence of significant differences of levels of participation according to variables such as age, gender, educational level and occupation. According to their results, the group of older less educated females is the one with higher rates of non-participation. In general, recent studies on adult participation in training provide a consistent profile of those adults that take part in it: young adults participate more than older adults, adults with higher qualification degrees engage more than adults with low qualification degrees, and the employed participate more than the unemployed (Daahlen \& Ure, 2009; Henry \& Basile, 1994; Illeris, 2003, 2006). Other studies (Boudard \& Rubenson, 2003; Carré, Aubret, Chartier, Degallaix \& Fenouillet, 2000; Desjardins, Rubenson \& Milana 2006) provide further nuances that indicate that the nature of an individual's job also influences the likelihood of a person participating in training; that is, jobs that are linked to new technologies and that require a high degree of literacy are related to higher levels of participation in training.

Reasons for participating in training are a recurring theme in the literature on adult education; that is, researchers have not only been interested in determining which adults engage in further training, they have also carried out studies to determine why these adults choose to do so. Such studies recognize the fact that adults are not a captive audience for educational institutions and that if they attend training courses or show an interest in lifelong learning is because they have reasons for doing so. For example, Houle (1961) classifies adult participants into three categories according to whether they are goal-oriented, activity-oriented, or learning-oriented learners. Tough (1968) argue that adults participate for pragmatic reasons (because they need to apply their new knowledge to practical experiences) or because they enjoy learning. Similarly, Cross (1981) indicates that the principal motivation for participating in training is a personal interest or pleasure in learning. Boshier (1977) carried out a study that identified two types of motivational orientation for participating in training: an orientation towards opportunity and an orientation towards development. People oriented towards opportunity tend to use training as a means of making up for some deficiency or achieving an external objective (getting a job, improving skills to better suit job-market requirements). People oriented 


\section{Renta-Davids et al-Adult's Participation in Work-related Training}

towards development tend to view training as a way of continuing to grow and stay up to date.

It is possible to extract some specific ideas that may help us to understand what motivates adults to participate in training. In the first place, the reasons for participating in training are many and might not be exclusive. There are no purely intrinsic or purely extrinsic reasons; participating in training may be motivated at the same time by a personal desire to learn about an interesting subject and by other goals such as obtaining a job or a promotion. In second place, the studies share the idea that motivation must be understood by analysing the interaction between the individual and his/her surrounding and that the motivation to participate is the result of the individual's perception of a particular situation. In third place, the studies suggest that adults have a certain control over their decisions and that the expectation that they will obtain some personal benefit is an important variable in their decision to participate.

Adults' motivations are social and historical constructions and therefore change according to the context. In this regard, Carré et al. (2000) argue that motivation assessment should be considered as a "snapshot of the relations that establish themselves, in a given context, at a given time, between a person and her/his environment". According to this author, a new approach to lifelong learning has emerged among adults that is marked by the current economic and social conditions such as competitiveness, knowledge economy, technological development, which demand adults to make a greater commitment to be 'apprentices' throughout their lives. For this reason, adults are increasingly "mobilized" to participate in training, but not necessarily "motivated" (Boudard \& Rubenson, 2003; Carré et al., 2000; Hight, 1998).

Carré's model defines two axes on which motivation is oriented: The first axis is formed by an extrinsic orientation versus an intrinsic orientation; and the second axis is formed by an orientation towards the acquisition of knowledge versus an orientation towards achieving objectives. Ten types of specific motivation emerge depending on how these axes are combined. Carré's results show two groups of participants that are clearly differentiated in terms of their personal characteristics and types of motivation. The first group includes older workers who are well-educated with high-ranking 
positions and who mainly have an operative-professional motivation for participating in training. The second group is made up of young adults who are poorly or less-well qualified and unemployed or with low-ranking positions; this group's motivations for participating in training are different from those of the group with operative-professional motivations (Carré, 2001). An interesting perspective offered by this model is that it presents an analysis that combines personal characteristics with types of motivation for participating, that is, the reasons for participating in training differ depending on the individuals' characteristics.

The principal focus of this article is people's motivations for participating in training. It brings together the evidence from previous studies which shows that participation in training is distributed unevenly throughout the adult population and that this is explained in part by individual differences. Likewise, the article also takes from previous studies the idea that people's motivation for participating in training is composed of multiple factors that are not mutually exclusive. Thus, a person's motivation for participating in training is different according to the type of training that is being analysed. In this article we will analyse what motivates people to participate in training related to work. It is clear that by analysing the motivation for participating in a very specific type of training (work related training), people's reasons for participating will be oriented in this direction; that is, towards obtaining work or maintaining and/or improving their current job. Even so, we still want to know if in addition to these reasons there are any others related to enjoyment of learning, personal development or social aspects. The presence of a type of motivation oriented towards enjoyment of learning or personal development would indicate a profile of participants who are mobilized not only by external conditions imposed on them by the requirements of their job and the need to immediately apply knowledge, but also by an internal motivation oriented towards learning and personal development. The article will focus on the Spanish context, and so before going any further, it will be useful to describe the nature of the continuous training system in this country. 


\section{The Spanish Tripartite Model of Work-related Training}

In the last decade lifelong learning in Spain has developed dramatically due to the implementation of specific public policies. The current model of professional training for employment was established by Royal Decree $395 / 2007$ of 23 March, and is the result of numerous agreements signed between the state, workers' associations and business associations. Currently, professional training for employment is organized under a tripartite model that is co-funded and regulated by the administration, the employers and the unions. The system of professional training for employment offers three types of activity: training that is offered by social agents; training that is organized by and responds to the demands of businesses; and complementary actions aimed at research and development.

Although the current training model was only created recently, the specialized literature contains some important studies that try to explain the way the system functions and the possible results that it gives rise to (Federación Española de Municipios y Provincias, 2009; Pineda, 2007; Pineda \& Sarramona, 2006; Ramírez del Río \& Garrido Casas, 2011). However, with one exception (Ramírez del Río, 2011), research in this field has usually been qualitative and has made no reference to the motivations of workers who attend this type of training.

Whereas the preceding studies have focused on how the employment training system functions in general and how it is managed and funded, and even though there is information on the rates of participation, it is still necessary to gather additional information on the reasons why adults participate in training in order to understand what motivates them to do so. This type of training is oriented towards employment; that is, its aim is to increase workers' employability. However, is this the reason why adults attend this type of training? Are there other reasons why they attend these courses? What motivates them to attend this type of training? Finding out the reasons why adults participate in employment training is fundamental for adjusting and orienting training to the needs of the participants and the organizations where they work or will work in the future.

Based on the theoretical view and on the empirical evidence presented, we purpose the following research question: 
1) What motivates adults to participate in work-related training?

2) Are there differences of motivation to participate among different demographic groups?

\section{Research Design}

The study relied on quantitative data collected from a questionnaire design for the purpose of this research. The questionnaire had three parts: the first part collected demographic data such as gender, age, level of education and employment situation; the second part included a list of 14 statements regarding reasons for participating in training based on a six-point Likert scale ( $0=$ totally disagree, $5=$ totally agree); and the third part included an open question where the respondents could indicate other particular reasons for participating in training. The statements regarding the respondents' reasons for participating in training reflect work-related and non-workrelated motives to participate which had been highlighted by previous studies (Chisholm, et al. 2004). Some of the statements had been used in previous studies into reasons for participating in lifelong learning programmes (Daahlen \& Ure, 2009; Illeris, 2003), whereas other questions were specifically created for the present study. The questionnaire was previously validated by research experts and was applied to a pilot sample of 10 adults. Three items were rewrite and occupational information was eliminated (job tenure, job category, organization size). The data analysis presented here is based only in the data from to the first and second part of the questionnaire.

An exploratory factor analysis was performed to reasons to participate item set of the questionnaire in order to reduce the dimension and obtain latent variables. The aim of the factor analysis is to simplify a matrix of correlation such that it can be explained in terms of a few underlying factors (Kline, 1994). Diagnostic analysis was done prior to the factor analysis to assure the data were suitable. We followed a diagnostic process described by Pérez \& Medrano (2010), Kline, (1994) and Tabachnick \& Fidell (2007) to check for violations of normality, linearity and multicollinearity. The results indicated that the data were appropriate for further analysis. Two factor 
analyses were performed by using principal component factoring method and oblique rotation. Direct-oblimin rotation was used because it was considered that the factors would be correlated (Cohen, Manion, \& Morrison, 2011; Kline, 1994; Tabachnick \& Fidell, 2007). To determine the number of factors we used parallel analysis procedures and screen-test examination. The first factor analysis was run without setting a priori criterion for the number of factors. The second factor analysis was run setting the a priori criterion for the number of factors after observing the screen-test. Finally, a decision was made to retain two factors after examining the screen-test, the eigenvalues and the model fit coefficient. Criterion variable scores were calculated using the mean score of each factor based on the items retained for each factor. All items were measured in a six-point scale so the variables had the same scale. High values of the variable represented a high presence of the feature measured. Independent variables such as gender, age, level of education and employment status were coded into categorical variables. Gender was coded 0 for man, 1 for woman. Age was coded into four categories: $1=18-24,2=25-34,3=35-44$, $4=$ more than 45 years old. Level of education was coded into three levels: 1=Compulsory Primary/Secondary Education (ISCED 0-3), 2= Postcompulsory (ISCED 4-5) and 3= University qualifications (ISCED 6-8). Labour status was coded in two categories, $1=$ unemployed and $2=$ employed.

As the aim of the study is to identify difference among groups in their motivations to participate, we performed an analysis of variance of the components extracted in the factor analysis in terms of the demographic characteristics. Analysis of variance is used to compare two or more means to see if there are any statistically significant differences among them (Tabachnick \& Fidell, 2007). One-way between-subjects ANOVA was run according to age and educational level and t-test was run for gender and employment status with a level of significance of 0.05 . When there were more than two groups to compare we carried out post-hoc contrast tests to identify in which groups there were a difference (Tahmane when variance was not homogeneous and Tukey when variance was homogeneous). Effect size was also calculated using the eta-squared coefficient and Cohen's d. Regarding data handling, we used FACTOR (Lorenzo-Seva \& Ferrando, 
2006) to compute the factor analysis and SPSS to compute analysis of variance.

\section{Sample}

Participants in this study were adults who were participating in training courses subsidized by the Professional Training for Employment Subsystem in Spain. Data were obtained using a self-administered questionnaire designed for this study. Three social organizations offering subsidized courses agreed to take part in the study, which allowed direct access to the participants. The courses in which the questionnaire was administered were chosen randomly, although one selection criterion was that they should be between 20 and 50 hours long. The courses dealt with different themes, but all were in the ambit of administration and marketing. In total, the questionnaire was administered in 40 courses during the month of September to December 2011. Participation rate in each course was 13 participants, with a range between 8 and 20 participants.

The questionnaire was administered in-situ during the classroom hours of the training courses. The researcher arranged a previous appointment with the each trainer who suggested the best moment to administer the questionnaire. On the day of the administration of the questionnaire, the researcher explained the purpose of the study, gave instruction for completing the questionnaire and distribute the forms. It was specified that participation was voluntary and data will be handled anonymously. In addition, a consent form to participate was distributed in a separate sheet. A total of 525 questionnaires were distributed and 499 were returned, yielding a response rate of $95 \%$ approximately of the total number of participants who were present on the day the questionnaire was administered. However, of the total number of questionnaires received, 74 had not been completed properly and were eliminated from the analysis, which meant that the sample was reduced to $\mathrm{N}=425$. The administration time of the questionnaire was 10 to 20 minutes, which included presenting the study, explaining the instructions for completing the questionnaire and filling the forms. 


\section{Results}

\section{Descriptive Results}

Table 1 presents descriptive statistic of the sample:

Table 1

Descriptive Results

\begin{tabular}{lcccc}
\hline \hline & $\begin{array}{c}\text { Compulsory } \\
\text { Primary/Secondary }\end{array}$ & $\begin{array}{c}\text { Post- } \\
\text { compulsory }\end{array}$ & $\begin{array}{c}\text { University } \\
\text { qualifications }\end{array}$ & Total \\
\hline Gender & & & & \\
Female & 38.03 & 49.66 & 69.57 & 57.41 \\
Male & 61.97 & 50.34 & 30.43 & 42.59 \\
Age & & & & \\
$18-24$ & 21.13 & 8.85 & 7.73 & 10.35 \\
$25-34$ & 19.71 & 31.29 & 47.83 & 37.41 \\
$35-44$ & 29.58 & 31.29 & 28.5 & 29.65 \\
over 45 & 29.58 & 28.57 & 15.94 & 22.59 \\
Labour status & & & & \\
Unemployed & 54.93 & 38.78 & 41.06 & 42.59 \\
Employed & 45.07 & 61.22 & 58.94 & 57.41 \\
Total & 16.71 & 34.58 & 48.71 & 1 \\
\hline $\mathrm{N}$ & 71 & 147 & 207 & 425 \\
\hline Note: & & & &
\end{tabular}

Note: data is shown in percentage

Of the total sample, $57.41 \%$ were female. The largest group of respondents were between 25 and 34 years old (37.41\%), followed by 35-44-year-old group (29.65\%). Almost half of respondents hold a university qualification (48.71\%), followed by respondents with post-compulsory education $(34.58 \%)$. Only $16.71 \%$ of respondents reported having compulsory primary and secondary education. Fifty-seven percent of the respondents were employed. The sample showed a similar distribution to the national statistics of participation in this type of training in terms of age and level of education 
whereas there were differences according to gender and occupational status (Fundación Tripartita, 2011). In the national statistic men participate more than women and the number of employed participants is greater than the number of unemployed.

\section{Factor Analysis}

Table 2 presents the results of the second factor analysis. As stated before, the first factor analysis was run without setting a priori criteria for the number of factors. The first analysis yielded three factors with a cut-off point of 1.0 for the eigenvalue. However, an examination of the screen-test suggested that two factors should be retained. To estimate the adjustment of the model, different indices were used including: Keiser-Meyer-Olkin (KMO) 0.83; Root-Mean-Square-of-Residual (RMSR) 0.085. With these results, the matrix structure with two components presented the best statistical indices of the adjustment of the model. The cut-off point was 0.40 for the items' loading to remain in the factor, as can be seen in Table 2. All the initial items remained in the factorial analysis because they showed an adequate load. The matrix structure shows the matrix of correlation between items and correlated factors whereas the rotated matrix offers a better interpretability of each factor. The factor correlation coefficient was .28 .

Table 2

Principal Component Analysis of Reasons to participate

\begin{tabular}{lccccc}
\hline \hline \multicolumn{3}{c}{$\begin{array}{c}\text { Rotated Matrix - Oblimin-Direct } \\
\text { Criterion }\end{array}$} & \multicolumn{2}{c}{ Matrix Structure } \\
\multicolumn{1}{c}{$\begin{array}{c}\text { Component } \\
\text { 1: learning } \\
\text { oriented }\end{array}$} & $\begin{array}{c}\text { Component 2: } \\
\text { Job-improvement } \\
\text { oriented }\end{array}$ & $\begin{array}{c}\text { Component } \\
\text { 1: learning } \\
\text { oriented }\end{array}$ & $\begin{array}{c}\text { Component } \\
\text { 2: Job- } \\
\text { improvement } \\
\text { oriented }\end{array}$ & $h^{2}$ \\
\hline $\begin{array}{l}\text { 7. Increase the chance of } \\
\text { getting a better job }\end{array}$ & - & 0.754 & 0.289 & 0.777 & 0.610 \\
$\begin{array}{l}\text { 9. Increase the chance of } \\
\text { getting a job }\end{array}$ & - & 0.740 & 0.106 & 0.714 & 0.518 \\
\end{tabular}




\section{Renta-Davids et al-Adult's Participation in Work-related Training}

Table 2 (cont.'d)

Principal Component Analysis of Reasons to participate

\begin{tabular}{|c|c|c|c|c|c|}
\hline & \multicolumn{2}{|c|}{$\begin{array}{l}\text { Rotated Matrix - Oblimin-Direct } \\
\text { Criterion }\end{array}$} & \multicolumn{3}{|c|}{ Matrix Structure } \\
\hline & $\begin{array}{l}\text { Component 1: } \\
\text { learning } \\
\text { oriented }\end{array}$ & $\begin{array}{l}\text { Component 2: } \\
\text { Job- } \\
\text { improvement } \\
\text { oriented }\end{array}$ & $\begin{array}{l}\text { Component 1: } \\
\text { learning } \\
\text { oriented }\end{array}$ & $\begin{array}{l}\text { Component 2: } \\
\text { Job- } \\
\text { improvement } \\
\text { oriented }\end{array}$ & $h^{2}$ \\
\hline $\begin{array}{l}\text { 8. Increase the chance of } \\
\text { changing job }\end{array}$ & - & 0.721 & 0.227 & 0.729 & 0.532 \\
\hline 2. Get a qualification & - & 0.749 & 0.070 & 0.712 & 0.524 \\
\hline $\begin{array}{l}\text { 6. Reduce chances of } \\
\text { losing job }\end{array}$ & - & 0.682 & 0.295 & 0.711 & 0.517 \\
\hline 5. Improve job prospects & - & 0.573 & 0.421 & 0.645 & 0.481 \\
\hline $\begin{array}{l}\text { 10. Be made to } \\
\text { participate }\end{array}$ & - & 0.574 & 0.015 & 0.536 & 0.305 \\
\hline $\begin{array}{l}\text { 3. Get to know new } \\
\text { people }\end{array}$ & - & 0.495 & 0.254 & 0.527 & 0.291 \\
\hline 1. Start a new business & - & 0.471 & 0.065 & 0.454 & 0.210 \\
\hline $\begin{array}{l}\text { 12. Increase knowledge } \\
\text { and skills in an } \\
\text { interesting subject }\end{array}$ & 0.806 & - & 0.763 & 0.036 & 0.605 \\
\hline $\begin{array}{l}\text { 13. Obtain useful } \\
\text { knowledge and skills for } \\
\text { work }\end{array}$ & 0.716 & - & 0.747 & 0.312 & 0.571 \\
\hline $\begin{array}{l}\text { 11. Obtain useful } \\
\text { knowledge and skills for } \\
\text { daily life }\end{array}$ & 0.700 & - & 0.685 & 0.138 & 0.472 \\
\hline 4. Do a better job & 0.620 & - & 0.674 & 0.367 & 0.491 \\
\hline $\begin{array}{l}\text { 14. Do new activities at } \\
\text { work }\end{array}$ & 0.478 & 0.308 & 0.562 & 0.438 & 0.404 \\
\hline$\%$ of Variance & 17,8 & 28,8 & & & \\
\hline
\end{tabular}

Note: Coefficients smaller than .30 were omitted in the rotated matrix. Coefficients greater than .40 are retained for that factor. Percentage of variance is post rotation. The eigenvalue of the third, not retained component was $1.17 . h 2=$ communality coefficient. 
The two extracted components reflect the orientation of adults' motivation to participate in training described in the literature, but with certain particular characteristics. The first component describes a motivation to participate in training that is oriented towards improving work perspective; that is, finding a job in the case of the unemployed and finding a better job or at least keeping their current job in the case of the employed. It includes items such as 'get a better job', 'change job', 'reduce chances of losing job', 'get a qualification', and 'improve job prospects'. It also includes the items 'get to know new people', 'start a new business', and 'be made to participate', although these have relatively low values. The second component describes a motivation to participate in training oriented towards the desire to learn about an interesting topic or to learn useful knowledge for use at work or at day-to-day life. It might be seen as a learning oriented motivation with practical connotations. In the light of these results, we decided to continue the analysis with these two components that emerged from the factor analysis. The components were given the names 'job-improvement oriented' and 'learning oriented' and scores were calculated for each component. The mean score for 'jobimprovement oriented' is 2.70 , and the mean score for learning oriented is 4.02. To answer the question of whether there is a difference among groups in their motivation to participate we conducted an analysis of variance for the categorical variables. Table 3 shows the results of these analyses.

There were significant differences in the mean score of 'jobimprovement oriented' motivation in different groups of age, qualification and labour status. In order to identify among which groups of age and qualification there were a significant differences, post-hoc test were examined. Additionally, the effect size was calculated using eta-squared coefficient. The results showed that the 16-24-year-old group had a significantly higher score in job-improvement oriented motivation (3.28) than the other groups of age $(\mathrm{F}=6.056 \mathrm{p}<.000)$. The eta-square coefficient was .053 , which express a moderate association. Furthermore, the results showed a significant difference in the score mean of each group of qualification $(\mathrm{F}=11.09 \mathrm{p}<.000)$. The group with compulsory primary and secondary education had the highest score (3.13), followed by the group with post-compulsory education (2.79) and the group with university 
education (2.47). The eta-squared coefficient was .054, also expressing a moderate association. Likewise, there was a significant difference in the score mean between employed and unemployed groups $(\mathrm{t}=4.420 \mathrm{p}<.000)$. The unemployed group had the highest score in this variable (2.96). Cohen's was calculated yielding an effect size of 0.41 , which is considered a moderate effect. None significant difference was found in 'learning oriented' motivation mean scores among different groups of the categorical variables. The gender variable has no statistically significant effect on scores for the two dependent variables in this sample.

Table 3

Type of motivation according to age, gender, qualifications and labour status

\begin{tabular}{|c|c|c|c|}
\hline & & $\begin{array}{c}\text { Component 1: learning } \\
\text { oriented } \\
\end{array}$ & $\begin{array}{l}\text { Component 2: Job- } \\
\text { improvement oriented }\end{array}$ \\
\hline & $\mathrm{N}$ & Mean & Mean \\
\hline \multicolumn{4}{|l|}{ Gender } \\
\hline Female & 244 & 4,05 & 2,66 \\
\hline Male & 181 & 4,02 & 2,73 \\
\hline \multicolumn{4}{|l|}{ Age } \\
\hline $16-24$ & 44 & 4,15 & $3,28 *$ \\
\hline $25-34$ & 159 & 4,01 & 2,68 \\
\hline $35-44$ & 126 & 3,99 & 2,48 \\
\hline more than 45 & 96 & 4,08 & 2,71 \\
\hline \multicolumn{4}{|l|}{ Qualifications } \\
\hline $\begin{array}{l}\text { Compulsory } \\
\text { Primary/Secondary } \\
\text { Education }\end{array}$ & 71 & 3,97 & $3,13 *$ \\
\hline Post-Compulsory Education & 147 & 4,14 & $2,79 *$ \\
\hline University Education & 207 & 3,98 & $2,47 *$ \\
\hline \multicolumn{4}{|l|}{ Labour Status } \\
\hline Unemployed & 181 & 3,96 & $2,96^{*}$ \\
\hline Employed & 244 & 4,09 & $2,49 *$ \\
\hline Total & 425 & 4.02 & 2.70 \\
\hline
\end{tabular}

Note: $(*)$ statistically significant difference $\mathrm{p}<.001$ 


\section{Discussion}

The aim of this study was to determine what motivates adults to participate in work-related training courses and whether there are any differences between different groups in terms of socio-demographic variables. Previous studies have found that adults have different motivations for participating in training. An individual's motivation for participating in training may be intrinsic, extrinsic, it may be related to social, personal or professional motives, it may be related to the individual's job or it may be related to reasons outside the sphere of their job. Most of the studies argue that this diversity of motivations is linked to individual differences and the different types of training to which they sign up.

In our study, a double orientation for participating in training emerges from the factor analysis of the reasons for participating in training. This analysis throws up two components; one was given the name 'jobimprovement oriented', and another 'learning oriented'. The first component was defined as a motivation oriented towards obtaining or keeping a job or getting a better job, whilst the second component was defined as a motivation oriented towards learning or acquisition of knowledge. This result is similar to previous studies that show that motivation for participating is a combination of different factors, be these social, personal or work-related (Carré et al., 2000; Chisholm et al., 2004; Illeris, 2003). For example, Chisholm et al. (2004) argue that motivation to participate in training and education tends to be mixed in nature as adults report both work-related and non-work-related motives to take part in education and training. Furthermore, these results also coincide with those presented by Houle (1961) and subsequently by Boshier (1977), who identified two types of motivation, one oriented towards opportunity and another one oriented towards lifelong development.

In our study, in general, 'learning oriented' has a higher score than 'jobimprovement oriented' suggesting that these adults in our sample are driven by their desire of gaining new knowledge in something that they are interesting in. This result is homogeneous across different groups when demographic variables are taking into account. None significant differences are observed in the mean scores of the groups studied or the 'learning 
oriented'. We may conclude from this that all individuals of the sample, regardless of their personal characteristics, are motivated to participate in training oriented towards finding out about an interesting subject that can be of benefit both in day-to-day life and at work. This result is related to the arguments offered by Tough (1968) who stated that those adults who participate in training are those who enjoy learning and who are motivated by the desire to use and apply what they have learnt. In the same vein, Cross (1981) suggests that those who participate in training are predisposed towards participating in learning activities, and that this is perhaps related to previous positive educational experiences.

However, if we look into job-improvement oriented motivation we found significant differences among demographic groups. This motivation is related to an external element such as labour situation and suggests an intention of attending a training course which could increase the possibilities of finding a job, changing a job or getting a better job. We may see this motivation as an instrumental attitude towards this type of training, as means of achieving other goals. For example, the youngest group has a high score in this motivation compare with the other groups of age. One possible explanation for this result is that young adults need to make up for certain areas in which they are needing such as lack of work experience or insufficient grades during their compulsory education, and this in turn might mean that they see work-related training courses as an opportunity to address this drawback.

In addition, the data shows that there are significant differences according to level of education. The findings suggest that adults with low level of qualification score significantly higher in job-improvement motivation than adults with high level of qualification, which in turn score low. Individuals with low educational qualifications might see this type of training as an opportunity to improve their position in the work market. Given the current socio-economic conditions, where qualifications are essential in the work market, having a lowed qualification is a clear disadvantage and these training courses are therefore seen by this group as a way of improving their position in order to obtain or keep a job or change to a better one. The low score in this variable for the group holding 
university qualifications could indicate that this type of training is less relevant for obtaining or keeping a job or changing to a better one.

Furthermore, the data show that there is a statistically significant difference in the mean score of the employed and unemployed groups. The unemployed group has a significantly higher score than the employed group in job-improvement motivation. This result suggests that unemployed adults are more concern than the employed adults in improving their background conditions which in turn could increase their likelihoods to find a job. We considered perfectly legitimate to attend work-related training driven by the motivation to improve future labour perspectives or prevent to lose current job. However, there is little evidence that this type of training effectively helps individuals to achieve this goal. For example, Chisholm et al. (2004) found that only $10 \%$ percent of adults who reported attending training to find a job or change a job succeeded in doing so as a result of their training. This issue raises other questions about fulfilment of expectation of work-related training.

This findings support Carré's (2001) theoretical view which state that there is certain a pressure on adults' involvement in work performance and, consequently in improving their qualifications. This is especially true for particular groups such as young participants, low-qualified workers and the unemployed. The increasingly based knowledge economy, changing skills requirements, and unemployment high rates are making adults to attend training more necessary than before. The findings in this study imply that it may be necessary to develop targeted policy instrument to help these vulnerable groups to find their way in an increasingly demanding labour market.

\section{References}

Boeren, E., (2011). Gender difference in formal, non-formal and informal adult learning, Studies in Continuing Education, 33(3), 333-346. doi:10.1080/0158037X.2011.610301 
Boshier, R. (1977). Motivational orientations re-visited: Life-space motives and the education participation scale. Adult Education, 27(2), 89-115. doi:10.1177/074171367702700202

Boudard, E., \& Rubenson, K. (2003). Revisiting major determinants of participation in adult education with a direct measure of literacy skills. International Journal of Educational Research, 39(3), 265-281. doi:10.1016/j.ijer.2004.04.007

Carré, P., Aubret, J., Chartier, D., Degallaix, C., \& Fenouillet, F. (2000). Motivations en formation d'adultes: Engagement et performance. Paris: Interface.

Chisholm, L., Larson, A., \& Mossoux, A. (2004). Lifelong learning: Citizens' views in close-up. Luxemburgo: European Centre for the Development of Vocational Training.

Cohen, L., Manion, L., \& Morrison, K. (2011). Research methods in education (7th ed.). London/New York: Routledge.

Cross, K. P. (1981). Adults as learners. San Francisco: Jossey-Bass. Daahlen, M., \& Ure, O. (2009). Low-skilled adults in formal continuing education: Does their motivation differ from other learners? International Journal of Lifelong Education, 28(5), 661-674. doi:10.1080/02601370903189948

Desjardins, R., Rubenson, K., \& Milana, M. (2006). Unequal chances to participate in adult learning: International perspectives. París: UNESCO.

European Commission. (2011a). Council Resolution on a renewed European agenda for adult learning, 2011/C 372/01.

European Commission. (2011b). Adults in formal Education. Policies and Practice in Europe. Brussels: Education, Audiovisual and Culture Executive Agency.

European Union. (2013). Adult and Continuing Education in Europe, Luxembourg.

Federación Española de Municipios y Provincias. (2009). Formación continua y modernización de la administración local: El reto de la evaluación del impacto. Madrid: Federación Española de Empresas y Municipios. 
Fundación Tripartita para la Formación en el Empleo. (2011). Balance de resultados 2010. Madrid: Observatorio de la Formación para el Empleo. Henry, G., \& Basile, K. (1994). Understanding the decision to participate in formal adult education. Adult Education Quarterly, 44(2), 64-82. doi:10.1177/074171369404400202

Hight, J. E. (1998). Young worker participation in post-school education and training. Monthly Labour Review, June 1998, 14-21.

Houle, C. O. (1961). The Inquiring Mind. Madison: University of Wisconsin Press.

Illeris, K. (2003). Adult education as experience by the learners. International Journal of Lifelong Education, 22(1), 13-23. doi:10.1080/02601370304827

Illeris, K. (2006). Lifelong learning and the low-skilled. International Journal of Lifelong Education, 25(1), 15-28.

doi:10.1080/02601370500309451

Johnstone, J., \& Rivera, R. (1965). Volunteers for learning, a study of the educational pursuits of american adults. Chicago: Aldine Publishing Company.

Kline, P. (1994). An easy guide to factor analysis. London/New York: Routledge.

Lorenzo-Seva, U., \& Ferrando, P. J. (2006). FACTOR: A computer program to fit the exploratory factor analysis model. Behavioral Research Methods, Instruments and Computers, 38(1), 88-91. Retrieved from http://link.springer.com/article/10.3758\%2FBF03192753

Pérez, E. R., \& Medrano, L. (2010). Análisis factorial exploratorio: Bases conceptuales y metodológicas. Revista Argentina de Ciencias del Comportamiento, 2(1), 58-66. Retrieved from http://www.redalyc.org/articulo.oa?id=333427068006

Pineda, P. (2007). La formación continua en españa: Balance y retos de futuro. Relieve: Revista ELectrónica De Investigación y EValuación Educativa, 13(1). Retrieved from http://www.uv.es/RELIEVE/v13n1/RELIEVEv13n1_2.htm

Pineda, P., \& Sarramona, J., (2006). El nuevo modelo de formación continua en España: Balance de un año de cambios. Revista de Educación, 34(1), 705-736. Retrieved from http://www.mecd.gob.es/revista-de- 
22 Renta-Davids et al-Adult's Participation in Work-related Training

\section{educacion/numeros-revista-educacion/numeros- anteriores/2006/re341/re341_29.html}

Pont, B. (2004). Improving access to and participation in adult learning in OECD countries. European Journal of Education, 39(1), 31-45. doi:10.1111/j.0141-8211.2004.00165.x

Ramírez del Río, A., \& Garrido Casas, J. (2011). Evaluación del impacto del esfuerzo formativo en la empleabilidad de los trabajadores en el contexto del modelo formativo tripartito español. Relieve: Revista ELectrónica De Investigación y EValuación Educativa, 17(2), 1-29. Retrieved from http://www.uv.es/RELIEVE/v17n2/RELIEVEv17n2_4.htm

Tabachnick, B. G., \& Fidell, L. S. (2007). Using multivariate statistics (5th ed.). Boston: Pearson.

Tough, A. (1968). Why adults learn: A study of the major reasons for beginning and continuing a learning project. Toronto: Ontario Institute for Studies in Education.

Ana Inés Renta-Davids is a Post-doctoral Researcher at the Faculty of Educational Science and Psychology at the University Rovira i Virgili.

Manel Fandos-Garrido is an Associate Professor at the Faculty of Educational Science and Psychology of the University Rovira i Virgili and technician of the Educational Science Institute (URV).

José Miguel Jiménez-González is a Professor at the Faculty of Educational Science and Psychology of the University Rovira i Virgili. Ángel Pío González Soto is a senior Professor at the Faculty of Educational Science and Psychology of the University Rovira i Virgili

Contact Address: Departament de Pedagogia, Universitat Rorvira i Virilgi, Ctra de Valls s/n, Zona Educacional, CP 43007.

Email: anaines.renta@urv.cat 